\title{
Questões regionais e a geografia econômica
}

\section{Maria Terezinha Serafim Gomes and Eliseu Savério Sposito}

\section{(2) OpenEdition \\ Journals}

Electronic version

URL: http://journals.openedition.org/espacoeconomia/15597

DOI: 10.4000/espacoeconomia.15597

ISSN: 2317-7837

\section{Publisher}

Núcleo de Pesquisa Espaço \& Economia

\section{Electronic reference}

Maria Terezinha Serafim Gomes and Eliseu Savério Sposito, « Questões regionais e a geografia econômica », Espaço e Economia [Online], 19 | 2020, Online since 01 September 2020, connection on 23 September 2020. URL : http://journals.openedition.org/espacoeconomia/15597 ; DOI : https:// doi.org/10.4000/espacoeconomia.15597

This text was automatically generated on 23 September 2020.

(c) NUPEE 


\title{
Questões regionais e a geografia econômica
}

\author{
Maria Terezinha Serafim Gomes and Eliseu Savério Sposito
}

1 Nos últimos anos, o Brasil passou por mudanças significativas, com crescimento expressivo do PIB (Produto Interno Bruto), da renda, do emprego, principalmente no período de 2003-2014. Nessa época, consolidou-se o que alguns chamaram de neodesenvolvimentismo, porém a política macroeconômica continuou a mesma do período anterior, dos anos 1990, com a adesão das políticas neoliberais e a lógica do capital rentista. A primazia do capital financeiro-rentista tornou-se avassaladora e contribuiu para o acirramento das desigualdades econômicas e sociais. O ciclo de crescimento do PIB e do emprego se encerrou em 2014. Observa-se uma alteração na participação da indústria na composição do PIB, somando atualmente $11 \% \mathrm{em}$ detrimento aos $20 \%$ dos anos 1980 . Diante desta constatação, estaria o país passando por um processo de desindustrialização ou por uma nova reestruturação/configuração dos espaços produtivos? Outro aspecto no que se refere à questão regional é pensar a integração regional em suas múltiplas escalas. $\mathrm{Na}$ atual conjuntura política e econômica em que o Brasil se insere há um "desmonte" da perspectiva de integração regional entre o Brasil e os países vizinhos. 
Maria Terezinha Serafim Gomes

Eliseu Saverio Sposito

QUESTÕES RECIONAIS EA

GEOGRAFIA ECONÔMICA

PERSPECTIVAS E DESAFIOS CONTEMPORÂNEOS

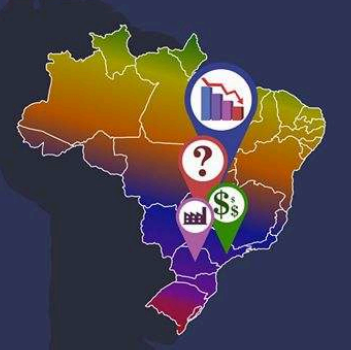

ERV 